\title{
RETRACTED ARTICLE: Sudden cardiac arrest under spinal anesthesia in a mission hospital: a case report and review of the literature
}

Bamidele Johnson Alegbeleye

The Editor-in-Chief has retracted this case report because of concerns about patient consent to publish. The content of this article is no longer available online to protect the privacy of the patient. The author has not responded to correspondence from the publisher about this retraction. 
Submit your next manuscript to BioMed Central and we will help you at every step:

- We accept pre-submission inquiries

- Our selector tool helps you to find the most relevant journal

- We provide round the clock customer support

- Convenient online submission

- Thorough peer review

- Inclusion in PubMed and all major indexing services

- Maximum visibility for your research

Submit your manuscript at www.biomedcentral.com/submit 